\title{
Pathetic Predicament and Resistance of the Subaltern in Trishna Gurung's Selected Songs
}

Tara Lal Shrestha ${ }^{i}$

Lecturer, Central Department of English, Tribhuvan University

Email: shresthatara@gmail.com

\section{Bidhya Shrestha ${ }^{\text {ii }}$}

Lecturer, Central Department of Population Studies, Tribhuvan University

Email: bidhya.shrestha@cdpl.tu.edu.np

\section{Dipankar Senehang ${ }^{\text {iii }}$}

Student of Fourth Semester

Central Department of English, Tribhuvan University

Email: senehanglims51@gmail.com

Bibechana Sharma Timsina ${ }^{\text {iv }}$

Student of Fourth Semester

Central Department of English, Tribhuvan University

Email: bibechanasharma@gmail.com

\section{Corresponding Author}

Bidhya Shresha

DOI: https://doi.org/10.3126/irjmmc.v2i3.40083

Received: August 09, 2021; Revised \& Accepted: September 17, 2021; Published: September 29, 2021

(C) Copyright: Shrestha (2021).

\section{ABSTRACT}

This article overviews the distress situation of the Nepalese ethnic subaltern concerning Trishna Gurung's five selected songs- "Sajha Ko Bela", "Gainey Dajai", "Khani Ho Yahmu", "Rail Lai Ma" and "Maya Man Bhari" and explores how the aesthetic expression and the pathetic predicament of the subaltern come to be a subtle form of resistance. Her songs hold the spirit of remoteness and auratic root and counter the western musical hegemonic propensity and the dominant music culture of Nepal. Articulating subaltern sighs as a major concern of her songs in the auditory and visual representation she presents the repressed aesthetics as a constructive and creative space formation for the resistance.

Keywords: Hegemony, pathetic predicament, representation, resistance, subaltern.

\section{INTRODUCTION}

Trishna Gurung, a newly emerged musical artist, has accumulated overtly popular recognition in the Nepali music industry in recent years. The artistic and auratic representation of the Nepali ethnic community, who are boycotted from mainstream politics, has made a greater impact upon the audience and music lover. The articulation of the outcast culture and depiction of cultural aesthetics have twinkled the charm of her songs. The 
illumination of the rural setting, the cultural attire of the artists, the portrayal of the countryside or organic Nepali musical instruments, for instance, madal, sarangi, bansuri and murchunga reflect the Nepali aura where the subaltern exists and speak more eloquently. Gurung's songs are not merely a musical representation of Nepal, but also the inner spirit of the boycotted people who endeavour for existence and resistance. The asymmetric division of power and uneven nature of political supremacy of majoritarianism, which has created hierarchies in the social realm, has always demanded a revolutionary movement to get space for the existence of the subaltern. The overwhelming dominance of elite groups of people over political, sociological, economical and cultural aspects has been acknowledged by the minorities and they are resisting the hegemonic tendencies through different social platforms and agencies. If we accept, as we assume we should, that no hegemony can be so penetrative and pervasive as to eliminate all ground for contestation or resistance, this leaves us with the question as to how we are to configure their presence, if it is not to be in terms of liberal humanist notions of subjectivity and agency (O'Hanlon, 1988). In this regard, Gurung's representation of subaltern music and auratic depiction is an exemplary resistive movement that counter-challenges the hegemonic discourse prevalent in Nepali society.

The cultural and musical enunciation of the subaltern in Gurung's songs resembles the possibility of resemblance and voices for the fugitive category of people. Avoiding the inability of articulation, she has made a terrific adumbration of the unrecognized dimension of society through the sound and visualization of music. Her songs, in the contemporary timeframe, pave the way for the encouragement of the subaltern through which they can be represented and resist the supreme forces that highly avoid them from their recognition and appreciation. Her songs are commendable entities for the oppressed that play a pivotal role in the subaltern consciousness and resistive forces. Emphasizing the boycotted frame of the society, she has tried to demystify the world of the subaltern and omit the hegemonies of western and dominant propensity. Advocating for the emphasis on the cultural and auratic root, she has created an artistic agency for the subaltern through which the large mass of people could be aware and conscious via the dissemination of musical discourse. Abstracting the issues presented in her selected songs, this paper tries to foreshadow two major issues that repeatedly occur dominantly: subaltern representative quality and the representative resistive consciousness aspects from within the expression of the pathetic predicament of the subaltern. Although some other songs even hold the same spirit, we, more importantly, selected these five songs in particular- "Sajha Ko Bela", "Gainey Dajai", "Khani Ho Yahmu", "Rail Lai Ma" and "Maya Man Bhari"- because, as we assume, these songs are the most suitable and appropriate selection that holds the real aura and soul of the subaltern in Nepal. These songs have been interpreted and analyzed with motives of how she preserves and presents the subtle resistance consciousness of the ethnic aesthetics through the expressions of the pathetic predicament of the subaltern.

\section{MUSIC AS AN AGENCY}

The music of the kingdom of Nepal embodies an important cross-section of the Asian history, culture, and geography, enormous in diversity, the crowning jewel of nearly onefourth of the Great Himalaya Mountain Range, encompassing the arctic climate of the world's highest peaks, the earth's deepest gorges as well as a wild tropical jungle (Bech, 1975). It 
embodies the diverse form of musical patterns and formulation deeply rooted in the diverse cultural dimension that facilitates the musical realm to enlarge and enrich. Elliott (1990) writes, "Music (like culture) is thoroughly mediated by concepts and expectations that are socially and historically determined" (p. 154). The music encompasses the shared beliefs and principles for listening to certain tones that contribute to the collective understanding and common knowledge. Delineating the process through which people can comprehend the socio-cultural aesthetics and transformation of it in the narrower and the broader sphere, it disseminates and accesses us to the unknown and the historical entity that a certain group holds. It is a form of mouth speaker through which history, culture and society are outspoken; however, the hegemonic tendency and dominant assumption always transcend the autonomous entity of music. The spontaneity of music is also disrupted by the superiority that persists. Neither history, neither culture nor society of Nepal, for instance, is mediated in democratic practices, rather it is engulfed with horrendous discrimination and cleavages. Historically sidelined by majoritarian history, culturally dominated by high elite ruling culture and socially excluded from the realm of democratic equality created demarcation resulting in a dichotomy as self and others, high and low, superior and inferior, privilege and unprivileged and dominant and subordinated. These superior qualities were accompanied by the dominant group and the outcast people became as Antonio Gramsci says, the 'subaltern'. Roy (2002) writes, "The very word 'subaltern', bringing in Antonio Gramsci into the theorisation, implies a battle, in this case, a battle to regain rights or resist processes of repression, subordination, and marginalisation" (p. 2224). This hierarchy still prevails hitherto, it is inhumane, undemocratic and non-acceptable, though. Thus, the tragedy is that Nepali music does not always sound as Bech (1975) illuminates, rather it also makes noise of resistance, retaliation, vengeance and demand for life, liberty, autonomy, equality and recognition as well.

Standing on the ground reality aforementioned, Gurung has remarked herself as a powerful representative to resemble the subaltern groups of people and their pathetic dimensions. Adhering to the governmental policy, Gurung has made an impressive representation in the field of music, bringing the Nepali cultural aesthetic into prominence. As in nations all over the world (Tessler, O'Barr, \& Spain, 1973), the government of Nepal tends to identify certain cultural traits as symbolic of national integrity and allegiance. Music, in particular, has taken on this function as the government has legislated against foreign music in favour of the creation of a national repertoire. The articulation of the predicament, that subaltern withstands, through the musical and visual depiction, affirms her as an agency through which the voices of those undead people are addressed. Nietzche (2017) writes, "Music is a counter renaissance development in the arts. It is also a form of decadence as the social expression" (p. 475). Gurung, through the music, expresses the social practices highlighting the subaltern's struggles to deflate the hegemonic tendency. She has not merely enjoyed her passion and the musical ecstasy but also, meanwhile, subtly advocated for the cultural aesthetic, sorrowfulness of minorities and the situation they confront. Although music does not, in itself, create hierarchies and discrepancies, not all songs are capable of addressing the exact location and essence of a particular theme. Carlos (2006) argues awareness, knowledge, and understanding are the most effective tools for selecting music with integrity. And such knowledge could be the strength of Gurung who has artistically represented the 
situation of the eroded people and has succeeded in presenting herself as a mouthpiece to the subaltern.

\section{LYRICS, REPRESENTATION AND RESISTANCE}

The contemporarily released musical words have the firm dominance of the western tendency, superimposing the auratic essence of the Nepali ethnic-socio community. The composition and selection of the music also represent the hegemonic tendency instead of picturizing the genuine setting into which the majority of the Nepali people live their life. However, Gurung, a contemporary singer, deliberately chooses the words that reflect the organic identity of the Nepali community and resists the hegemonic tendency through the powerful lyrics of the songs. Often representing the Gurung community in her songs, she is providing the power to the resistive groups to confront the oppressiveness present in society. As Foucault (1978) argues, "Where there is power, there is resistance, and yet, or rather consequently, this resistance is never in a position of exteriority in relation to power" (p. 95), the song "Sajha Ko Bela" broadcasted on 9 May 2016 picturizes the rural area, explicitly representing the culture of the Gurung community through the characters belonging to the community has been provided with the power to unfold the flattened self of the subaltern groups:

$\begin{array}{ll}\text { साँकको बेला रमाइलो मेला } & \text { Mirthful fair in the time of dusk } \\ \text { घुम्न हिडेंको बेला } & \text { At the time of the tour } \\ \text { चौतारीमा कुरी बसेको छो कि कतै मलाई Have you been waiting for me in the } \text { chautari }^{l} \text { ? } \\ \text { पिरतिले मेरो तान्यो कि कानछा } & \text { Did my love pull you, my beloved } \\ \text { आज तिमीलाई मै तिर } & \text { you today, towards me } \\ \text { माया मोह } & \text { Love and affection } \\ \text { यसरी नै लाने हो } & \text { Just like this to be } \\ \text { संगाली राखेछु मनमा धेरै कुरा } & \text { Accumulated a lot of talks within to share } \\ \text { कसरी भनु कसरी पोखु मनका कुरा... } & \text { How to say, how to express them all } \\ \text { डाँडैमा बसी परको गाउँलाई हेरा... } & \text { Observing a far-flung village sitting on the hill (Our Trans.) }\end{array}$

The lyrics of the song encompasses the valorization of the evening time when people gather and share the mirthful events they have experienced with the beloved. Electing fundamental aspects such as 'chautari'- a familiar place used by the common people to meet and express their love, in the lyrics- Gurung is resisting the hegemonic tendency of celebrating love in a pop culture setting. Further, through the representation of a naturalistic scenario, she is subtly demonstrating the position of the subaltern which is neither completely established nor dilapidated like dusk. The lyrics have been used as a resource to present social activities in which the subaltern's euphoric sense resides. As music is a bio-cultural resource, a sound-producing activity natural to humans that comes into being as music through sociocultural processes, then efforts to sustain music are best directed at, and regarded as, sustaining selected socio-cultural activities that encourage music's production and maintenance. In short, sustaining music means sustaining people making music (Titon, 2009). The lyrics of Gurung sustain the thought of the people with the cruciality of the representation of the culture, eliminating the suppressive western tendency.

\footnotetext{
${ }^{1}$ A cool resting place under the trees for social gathering.
} 
The indigenous subaltern groups of people and their surroundings have been represented in the form of lyrics in Gurung's songs. The song "Gaine Dajaile" has elucidated the unnoticed musical artist as a prominent subject matter of her lyrics:
गाइने दाजैले सारङ्गी रेट्दामा
When gaine brother plays the sarangi
हुरुक्कै हुनछ मन मेरो ए साइला तिमीलाई देख्दामा
छम्छमी नाच्छु भन्थे डम्फुको तालैमा
My heart leaps up, dear beloved when I see you
ढुकढुकी मेरो बढ़छ, नी ए साइला तिमीले हेर्दामा
I wish to dance to the beat of damphu
My heartbeat increases when you see me. (Our Trans.)

In the lyrics above, the vibration of the subaltern representation as the volcanic eruption can be perceived which is expressed in articulative form rather than the revolutionary attitude. The word "Gainey Dajai" dispenses the auratic vocals of the subaltern people, who are living in Eastern Nepal. He, the subaltern character with the subaltern musical instrument sarangi, has the power to spread amusement among the people. Through the lyrics of the song, both undermined subaltern's aesthetics express their walk in the path of commonality to spread a sense of love in the community. The trivial figuration of the subaltern group by the hegemonic group has been eliminated through the song revealing the message that the subaltern has a voice and through the medium of music, they comprehend the meaning they hold to the world. The significance provided to the sidelined subaltern musical instrument dampu resists the pop culture tendency of the west as it makes the heart of the character leap up with excitement and dance reflecting their culture. Moreover, it distributes the message that the music holds the societal aspects and shares it with the listeners passing the message that music is not an autonomous entity. It is not music technologies alone that are changing our ways of thinking about music. There is also a profound social restructuring worldwide in scope taking place, which already has left its mark on the music of many cultures (Roehmann, 1995). The structure of lyrics is structured through the culture it marks. Life in the song is based on the representation of eloquence, traditions and values which reflects the culture of the community.

The subaltern groups of people for the sustainability of their identity are forced to adopt the identity marching far away from the homeland. Gurung in the lyrics of the song "Khani Ho Yhamu" dispenses such a tragic situation of lovers because of the departure of a boy from his beloved which depicts the struggle that the subaltern groups have to walk through for the formation of their identity. As the stanza goes:

कम्मरमा पोको निधारमा डोको

ओठैमा हाँसो लिइ

म पनि जान्छु तिमीसँगै म पनि जान्छु रे

खानि हो याम्हु ए कान्छा

खानि हो याम्हु ए
Placing poko on the waist doko on head

And smile on your lips,

I'll go along with you, I'll go with you

Where are you going, oh Kanchha?

Where are you going, oh?

The line depicts the sorrowful situation of the lady when a man talks about his plans to fly abroad resembling the struggle oriented lives of the subaltern to obtain prosperity. Gurung, through the song, presents the loss that the subaltern community has to experience because of unwilling obligations and tendencies. The hierarchies prevalent in society ever segregate people and inoculate discrepancies of exclusion. The excluded people lament and remain in longing for rights and recognition existing in the community. As Shin Taech'ol (2001) claims, “...communally based music can- and often do- operate under strictly defined hierarchies 
(anathema to democratic principles), while, theoretically speaking, egalitarian participation could represent everyone involved being treated equally badly, resulting in the loss of the sense of the common good" (as cited in Hesselink, 2010, p. 674). Through the picturization of the two characters, the songs pass the message of the loss, struggle, sacrifice that the subaltern groups have to experience and are bound to dream of having a prosperous life in their own territory because of the oppressiveness of the dominant concept. Besides, it represents the typical situation of the subaltern people that the prosperity in the life of the subaltern arrives only after he leaves his homeland, leaving his beloved full of tears. The autonomous self of the subaltern has been victimized, making them struggle for identity. Gairola (2002) shares, "Identity itself can be viewed as a reflexive 'gift' stuck in a churning network of identities within the ideological constraints of society...The relationship between agency and subjectivity is inextricable; our identities are functions of the ways in which others construct us" (p. 308).

The words of the songs of Gurung encompass the devastating situation that the subaltern group experiences while constructing their identity. How the subaltern has to function on the path constructed by the hegemonic group can be viewed in her lyrics. The pathetic dissemination of the subaltern groups to a foreign land to be labelled as 'inferior workers' in spite of having love for their family and country has been bestowed in the lyrics of the song "Rail Lai Ma":

रेलैमा चढी काटि उकाली ओराली

गर्दे सबैलाई बिदाई लागें म

मन्द हावाले छुँदा कन्

किन भस्किरहन्छ, मन

सम्भिक मायालुको देशै लागें म
Travelling in the train, across upward-downward slopes Bidding farewell to all, heading I'm. When breezes touch, why my heart Why is my heart paining

Reminiscing the country of my beloved, heading I'm.

The use of the transportation rail (train) resembles the compressed economic condition of the person belonging to the subaltern group and the words such as ukali-orali provide us with a sense of the hilly area of Nepal. The problem we find in most contemporary songs is the dearth of socio-cultural essence and Gurung valorizing the cultural aesthetics have countered the dominant features. Presumably, then, the reasonable solution is to focus on the specific aesthetic qualities of art so that sensitivity may be developed to those things which determine the value of all fine art (O'Grady, 1977). Gurung's focus on aesthetics is a solution as musical activities value the ideologies that shape the community to be a better place, annihilating the hegemonic tendency that has squashed the auratic essence of the indigenous group. Conjoining music, dance and ritual language within an event that addresses the existential concerns of the community are the most universally valued of musical activities (Trehub, Becker, \& Morley, 2015). Culture reflecting dance, language, rituals holds the universality as it presents the lively aesthetics of the community. The assemblage of the genuine practices of the community valorizes the existence of the subaltern groups. Gurung's deliberate selection of the auratic setting in the realm of the industry has firm control upon the dominant class which can be illustrated through the lyrics of the song "Maya Maan Bhari" which presents the essentiality of love for the human being and the preservation of cultural aesthetics. Emphasizing the affinity of the subaltern groups to the rustic setting, their 
utilitarian behaviour Gurung chooses the countryside instead of the industrial area or cosmopolitan setting for the valorization of the culture in an auratic manner:

$\begin{array}{ll}\text { जुनतारा लाग्यो कल्मल दिनै छ, घमैलो } & \text { Moon and stars gleamed, sunny is the day } \\ \text { तिमी हुँदा साथैमा लाग्छ नी रमाइलो } & \text { Your presence spreads amusement } \\ \text { मायाले सम्भिदा लागछ, नी बाडुली } & \text { Remembrance of beloved brings hiccups } \\ \text { मायालाई बोलाउन गाउछु म मारुनी } & \text { To call my beloved I perform maruni } \\ \text { डाडैको वरपिपल चौतारी } & \text { Banyan-peepal parlor on the hill } \\ \text { बिसाउदै भारी } & \text { Resting the loads } \\ \text { त्यो ज्यानलाई पर्खी बसेछु } & \text { Waiting I am for your soul } \\ \text { मै बाटो हेरी... } & \text { Looking on the street... (Our Trans.) }\end{array}$

The lyrics represent the everyday life of the people living in the village area and the selection of music indicates the brilliant craftsmanship of the composer in presenting the live picture of people in the village area. The moonlights that are covered in the city lights can be perceived through the rural area with its auratic features; this represents the natural lights that beautify the rural setting. Moreover, the insertion of the cultural dance (maruni) reflects the artistic way to call the beloved celebrating the cultural aesthetics. Along with, Gurung has captured the subaltern myths and beliefs in the lyrics, the myth that is practised in countryside areas. For instance, the emergence of hiccups, in the lyrics, can be regarded as the symbol of remembrance of love. The art of music contributes to the development of the social periphery, marking the fallacies directly and indirectly. If art is social, in other words, it is social in its own way, on its own terms, and by way of making its own distinctive yet contingent contribution within specific social and historical circumstances (Shepherd, 1994). Through the music, Gurung represents the subaltern people and their historicity which has been flattened, folded and left out for extinction because of a hefty hegemonic tendency. The representation of the fundamental blocks through which the Nepali community has built through the songs can be comprehended as the resistive forces that have been confronting the entire global tendency instead of Nepal. Moreover, it also debunks the persisting hegemonic tendency that has ruled over eradicating the root into which the community forms. The priority to the subaltern in the songs presents the voices of the groups that have been deliberately rejected and silenced.

The work of Gurung focuses on the presentation of the aesthetic roots, the reality of the subaltern through the music embracing the erasure of the deliberate suppression into which the subaltern groups are forced to live. Her work counterattacks the persisting hegemony upon the subaltern groups. Representing the subaltern's hard work, she boycotts the hegemonic tendency and also passes the message that the subaltern can speak. The real power of music lies in the fact that it can be "true" to the life of feeling in a way that language cannot; for its significant forms have that ambivalence of content that words cannot have (Langer, 1954). Therefore, the subaltern speaks through the music and confronts the oppressive tendency as music has the power to resist reclaiming the culture and picture cultural aesthetics.

\section{CULTURAL REFLECTION FROM BELOW}

Gurung's cultural representation has been gaining popularity amid an increase in western culture which asserts that the people, even though they are influenced by the western 
tendency, do not want their culture to fade away. The preservation of aesthetics has always been the priority as it binds the people with perspectives in her songs. The insertion of traditional musical instruments like sarangi has been maintained, passing the message of the existence of local culture. The struggles-oriented lives of the subaltern groups compressed within the perseverance of the culture and the formation of the identity can be perceived in her songs as the ideologies that are ignored after the emergence of the influence of the western culture.

Gurung's song had endeavoured to foreshadow the subaltern instruments and their musical aesthetics through the visual representation in "Gaine Dajaile".

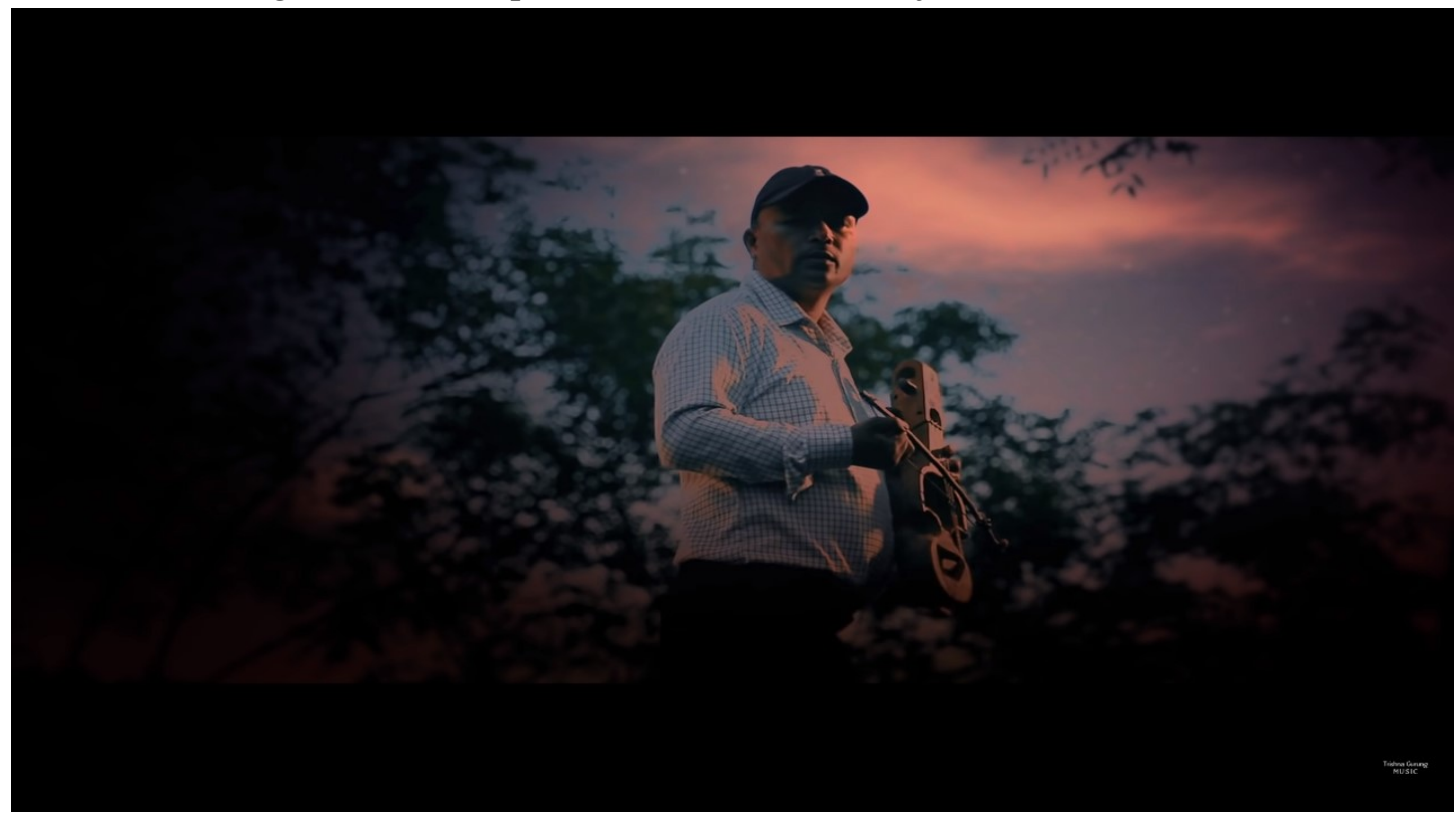

Fig 1: Gainey Dajai

Sarangi, a very common and typical Nepali instrument made and played significantly in the countryside, is a powerful symbol to represent the subaltern's aesthetic. Although it is played in the urban settings as well, it has an auratic linkage with the peasant and downtrodden's musical instruments. This musical instrument picturized in the song affirms the subaltern representation and the form of resistance by exposing it to the dominant discourses.

The cultural attire and aesthetics are the dominant factors that Gurung presents in her music videos. Her cultural consciousness is remarkably induced in the musical ground which has a firm root in the visual display of her song. The cultural attire by the leading character in the music videos is recognized as the vigorous endeavour to convert marginal into widely known. The national attire of Nepal- daura suruwal- is the dominant cultural clothes that have got wider recognition, but there are more than 126 ethnic groups in Nepal, and every ethnic group varies in terms of cultural attire as well. Canon is interested in how one survives with integrity when one is systematically excluded both by and from moral, aesthetic, and spiritual norms as articulated by the dominant culture, and yet still judged against and by those same norms. A subaltern person may at the same time both endorse and resent such norms. In such a situation, one must compromise a great deal and canon negotiates this by bringing together 
concepts that most ethicists would keep apart (Howe, 2003). Gurung in her song has tried to resist the hegemonic and dominant cultural attire and has represented her own (Gurung) culture that metaphorically counter-challenges the high culture and brings forth the subaltern's aesthetics. The song "Sajha Ko Bela", for instance in figure 2, shows the cultural presentation of the leading actress.

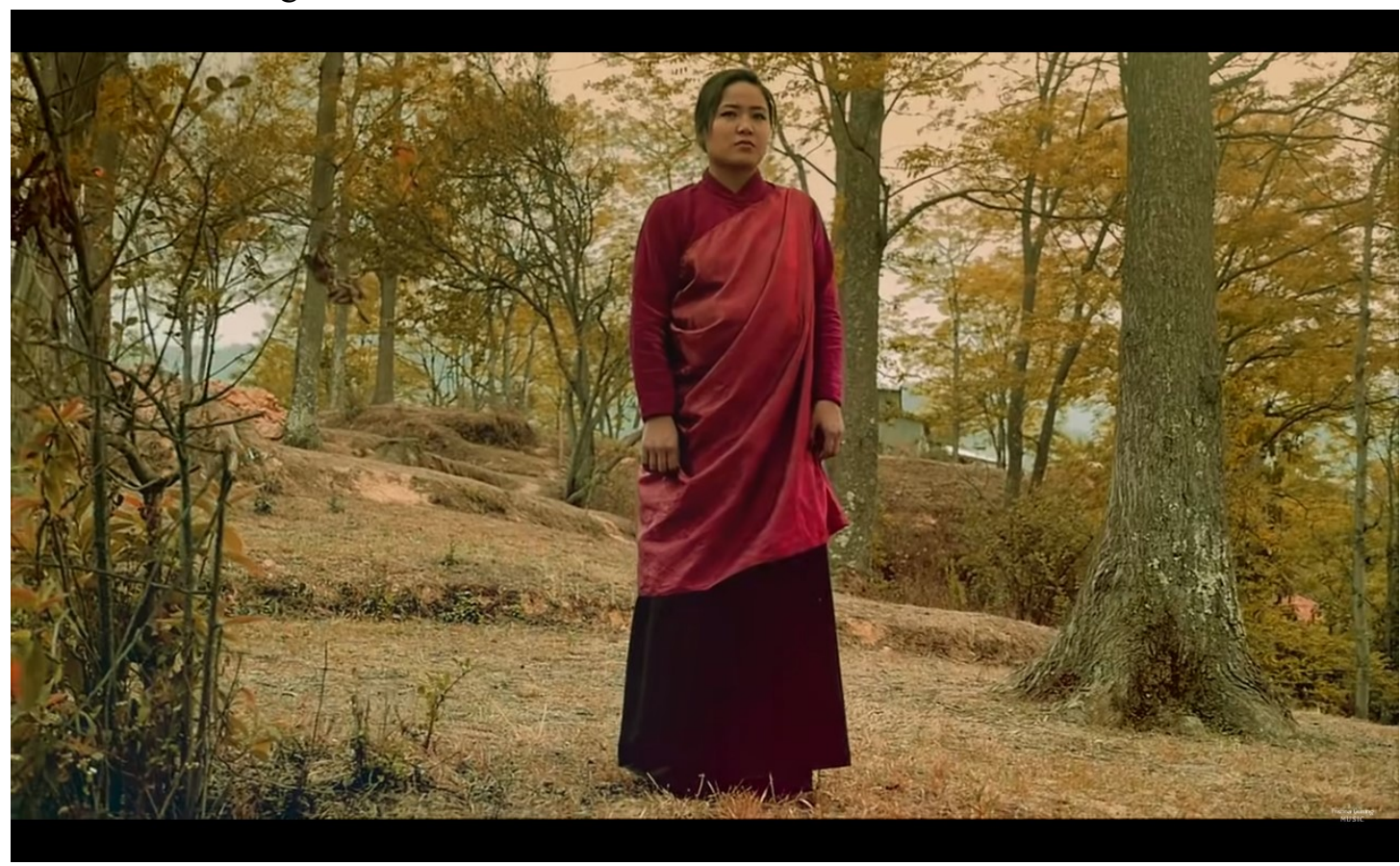

Fig 2: Sajha Ko Bela

It is not a mere accident that Gurung presents cultural consciousness in her selective songs rather a deliberate and subtle enunciation of her cultural affinity. Almost all of her songs represent the indigenous cultural aesthetics of rural Nepal. An exemplary song, "Khani Yo Yhamu" presents the story of the characters belonging to the Gurung community and highlights the struggle about the subaltern groups shattering the persisting hegemonic tendency that has not let the people belonging to the subaltern community uprising. Gurung through her song reveals the pain of the subaltern who has to travel a long path for the formation of the identity putting their life at risk. The music here functions to educate the general public about the significance of the cultural aesthetics, territory, values, beliefs and the deliberate imposition of power to keep the subaltern groups in the subservient position. The functions of musical education- just as education, in general, are also very important in a musical culture defined by the coexistence of risks and opportunities (Baltzis, 2005). Music in the form of entertainment educates people about the pivotal characteristics of the indigenous values, beliefs and traditions with the message to eradicate the planned conspiracies of the hegemonic and the western tendency to uproot the aesthetics that the group holds.

Gurung's songs valorize the rustic setting for the authentic representation of the cultural beliefs, values, traditions and aesthetics which reflects a concrete and meaningful shape of the indigenous community. The essence of the moon and stars can't be visualized in the city lights, the rustic setting is necessary for the representation of the true way of life that the community has. The choice of the rustic setting in Gurung song is a deliberate act because 
the rustic setting inclusively represents the voice of the subaltern, as Gramsci (1992) opines, "Every social group, coming into existence on the original terrain of an essential function in the world of economic production, creates together with itself, organically...intellectuals which give it homogeneity and an awareness of its own function not only in the economic but also in the social and political fields" (p. 5).

For instance, figure 3 extracted from the song "Maya Man Bhari" flows the message of everyday life of the women in the rural areas whose beloved have been away from home.

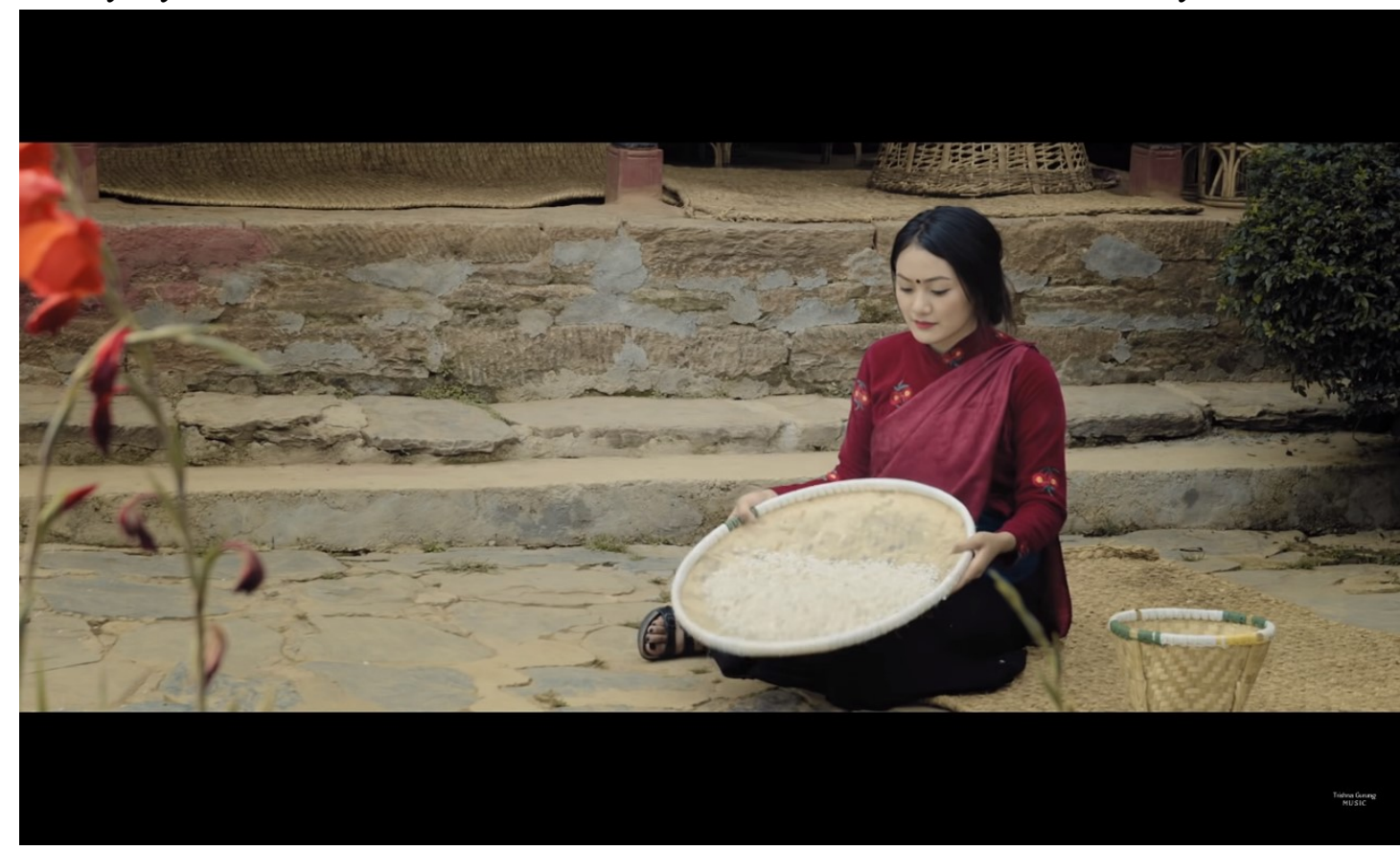

Fig. 3: Maya Maan Bhari

The cultural resemblance is the figurative assertion that she makes in her songs. Since culture is as Gramsci calls 'the expression of society', it represents not merely a certain individual rather a huge mass of people. It clarifies dominion against certain cultural groups is also the dominion over a huge category of people. In this regard, Gurung in her song, representing Gurung culture, is an alternative space that is highly subordinate. As Elliott (1990) writes, "Culture is generated by the interplay between a group's beliefs about their physical, social, and metaphysical circumstances and the linked bodies of skills and knowledge they develop, standardize, preserve, and modify to meet the intrinsic and extrinsic needs of the group" (p. 149), Gurung's representation of Gurung culture in her music videos gratifies the cultural entity not of her particular but a huge mass of people. The representation in her songs and videos illustrates herself as an agency with the entanglement of power and musical intoxication.

\section{ADMIXTURE, BLEND AND SHIFT}

The contemporary Nepali music, most dominantly, has been inoculated by the hegemonic discourses and have been set apart from the cultural and Nepalese roots. The popular tendency has colonized their mind and has derailed them from the real track. The dichotomy created in Nepali music as popular and native has sidelined the indigenous orality which has been debunked by Gurung in her songs. For instance, "Rail Lai Ma Chadi," and 
"Gainey Dajailey" have dominantly embedded both subtle musical instruments and resisted the subordination of subaltern musicality. More importantly, her stress upon the indigenous aesthetic and musicality expresses as an antidote to free their mind from the colonized propensity of music. As Ingle (2017) asserts,

One music reigns supreme, while the other is neglected at best or dies away at worst. The "either/or" "colonial" approach is not healthy or even desirable for a flourishing culture. Thus, the necessity to "decolonize" our music. Decolonizing music involves a conscious decision to move away from an "either/or" "colonial" mentality to a "both/and" "decolonized" mentality. Decolonizing music, however, is not about replacing one style or genre with another. Replacing "colonial" music with indigenous music only perpetuates the "either/or" mentality that has always been destructive to our music, just with a different style becoming preeminent. We must be open and accepting of new music as well as old, of classical music as well as popular, improvised music as well as notated, and on it goes. (p. 17)

Subverting supremacy is necessary for the sustenance of the subaltern people and their aesthetics. Gurung has shown her craftsmanship to blend popular culture with music in a subaltern setting. The fusion of western tendencies, musical instruments like keyboard, drum and guitar with typical Nepali instruments is an attempt to decolonize the musical realm and reinforcement of the subaltern musicality and its consolidation. The admixture has created a new texture that works as a resistive mechanism and representative voice on behalf of subalternity. For instance, Gurung herself articulating with the guitar the music video illuminates the blend of musical composition and performative appearances.

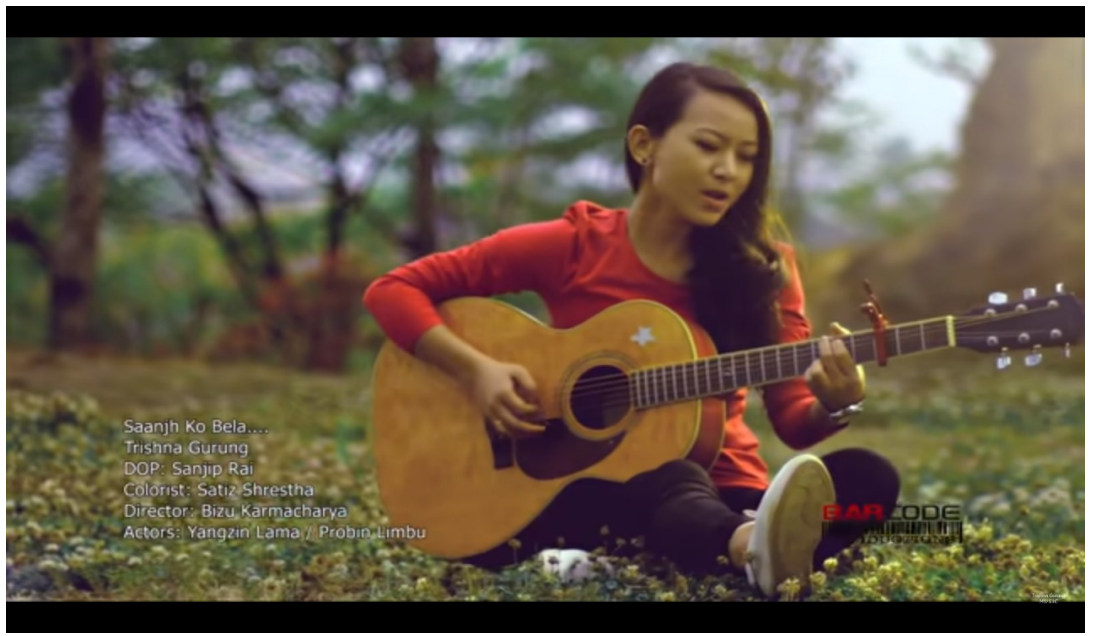

Fig. 4: Trishna with her guitar

The admixture of the modern musical instrument- the guitar and the traditional musical instrument- the sarangi, shows the progressive ties between the original and the western culture. Moreover, this amalgamation is not only the representation of shifting but 
also an effectual progression to represent the subaltern to the global periphery. It is a significant process to internationalize the issue of the subaltern representing them through the pleasure of music. Gurung's attempt to adhere to the musical admixture is a new step of energizing the issues and changing its stagnated location to positionality. The assemblage of people, setting, culture, musical instrument lyrics and aesthetics have played a pivotal role in the prolonged and elevation of subaltern resemblance. According to Berry (2013),

Assemblage not only accommodates the kind of flexibility that maximises profit in flexible production as witnessed... but also makes space for the connections that drive a non-profit organisation... Indeed, it is possible that part of the challenge of understanding this new logic of assemblage may be the need to grasp that not only does it do all these things at once, but also that this may be crucial to its strength and development. (p. 496)

Gurung's deliberate attempt to present musical newness i.e the blend of subaltern and popular tradition is a prolific attempt to largely represent the subaltern world and their musicology in the global periphery. This attempt has created a tremendous space for the subaltern to position themselves.

\section{CONCLUSION}

The representation and the resistive voices are vehemently presented in Trishna Gurung's selected songs which play a significant role to address the reality of subaltern. Presenting the pathetic dimension of the subaltern, she has made a remarkable reflection and advocated for the astounding resistance through her songs. The composition of the music, musicality and visual depiction has paved a new way for resistive forces through which huge masses can be aware simultaneously. Positioning the subaltern as the dominant force in her songs, she has elucidated the strength, organic entity, aesthetic sublimity, resistive materiality and unavoidable social reality of the subaltern. In association with the portrayal, exposing ample division of society, she has played a role of an agency to address and locate the voices of the subaltern. To a higher degree, she has accumulated the power and uses it as an imperative apparatus- to disseminate the aura of the boycotted group and located the positionality and acknowledged those unacknowledged groups of people. The way she has presented herself as an agency is the demand of subaltern; her exemplary work has changed the entire scenario and comprehension of music and musicology with the spirit that music is not merely a sound and source of pleasure, rather it encapsulates the social dimension and humanistic root as well. The aesthetic expression and the pathetic predicament of the subaltern through her selected songs come to be a subtle form of resistance to the Nepalese ethnic subaltern as a hope for the formation of counter-hegemonic space.

\section{REFERENCES}

Abril, C. R. (2006). Music that represents culture: Selecting music with integrity. Music Educators Journal, 93(1), 38-45. doi:10.2307/3693429

Baltzis, A. G. (2005). Globalization and musical culture. Acta Musicologica, 77(1), 137-150. Retrieved from http://www.jstor.org/stable/25071251

Baltzis, A. G. (2005). Globalization and musical culture. Acta Musicologica, 77(1), 137-150. Retrieved from http://www.jstor.org/stable/25071251 
Bech, T. (1975). Nepal: the Gaine caste of beggar-musicians. The World of Music, 17(1), 28-35. Retrieved from http://www.jstor.org/stable/43615721

Berry, C. (2013). Transnational culture in east Asia and the logic of assemblage. Asian Journal of Social Science, 41(5), 453-470. Retrieved from

http://www.jstor.org/stable/23654795

Elliott, D. J. (1990). Music as culture: Toward a multicultural concept of arts education. Journal of Aesthetic Education, 24(1), 147-166. doi:10.2307/3332862

Foucault, M. (1978). History of sexuality vol.1: An introduction. In Robert Hurley (trans.). New York: Pantheon Books.

Gramsci, A. (1992). Selections from the prison notebooks of Antonio Gramsci. In Quontinhoare and Geoffrey Nowell Smith, (ed./trans). New York: International Publishers.

Gurung, T. (Singer). (2016, October 26). Gainey Dajai -Trishna Gurung [Official Video] [Video]. Youtube. Retrieved from https://www.youtube.com/watch?v=c1aONU7aQ4o

---. (Singer). (2017, January 24). Khani Ho Yahmu - Trishna Gurung [Official Video] [Video]. Youtube. Retrieved from

https://www.youtube.com/watch?v=KQW6iPOTwAY

---. (Singer). (2019, August 8). Maya Maan Bhari - TRISHNA GURUNG

[OFFICIAL VIDEO] [Video]. Youtube. Retrieved from https://www.youtube.com/watch?v=3EFDJZ5TZ14

---. (Singer). (2017, November 5). RAIL LAI MA - TRISHNA GURUNG [OFFICIAL VIDEO] [VIDEO]. Youtube. Retrieved from https://www.youtube.com/watch?v=nSJ6vQ-Uo-s

---. (Singer). (2016, May 9). SAJHA KO BELA - TRISHNA GURUNG [OFFICIAL VIDEO] [Video]. Youtube. Retrieved from https://www.youtube.com/watch?v=X7Yk9IDEOxA

Hesselink, N. (2010). Taking culture seriously: Democratic music and its transformative potential in south Korea. The World of Music, 52(1/3), 670-701. Retrieved from http://www.jstor.org/ stable/41700053

Howe, L. E. (2003). Ontology and refusal in subaltern ethics. Administrative Theory \& Praxis, 25(2), 277-298. Retrieved from http://www.jstor.org/stable/25610610

Ingle, G. L. (2017). Decolonizing Music: The Music Forum of the Americas. American Music Teacher, 67(2), 16-18. Retrieved from https://www.jstor.org/stable/26385827

Langer, Susanne K. (1954). Philosophy in a new key. (6 ${ }^{\text {th }}$ ed.). New York: The New American Library.

Nietzche, F. (2017). The Will to Power. In R. Kevin Hill (ed.), R. Kevin Hill and Michael A. Searpitti (trans.). New York, UK...: Penguin Classics.

O'Grady, T. J. (1977). High culture and music education. Journal of Aesthetic Education, 11(1),109-111. doi:10.2307/3331869

O'Hanlon, R. (1988). Recovering the subject subaltern studies and histories of resistance in colonial south Asia. Modern Asian Studies, 22(1), 189-224. Retrieved from http://www.jstor.org/stable/312498

Rahul Gairola. (2002). Burning with shame: Desire and south Asian patriarchy, from Gayatri Spivak's "Can the Subaltern Speak?" to Deepa Mehta's "Fire." Comparative Literature, 54(4), 307-324. doi:10.2307/4125368

Roehmann, F. L. (1995). Technology, culture, and music. College Music Symposium, 35, 124-131. Retrieved from http://www.jstor.org/stable/40374274.

Roy, T. (2002). Subaltern studies: Questioning the basics [Review of Reading Subaltern 
Studies: Critical history, contested meaning and the globalisation of south Asia, by D. Ludden]. Economic and Political Weekly, 37(23), 2223-2228. Retrieved from http://www.jstor.org/stable/4412215

Shepherd, J. (1994). Music, culture and interdisciplinarity: Reflections on relationships. popular music, 13(2), 127-141. Retrieved from http://www.jstor.org/stable/853206

Tessler, M. A., O'Barr W. M. , \& Spain, D. H. (1973). Tradition and identity in changing Africa. New York: Harper \& R.

Titon, J. T. (2009). Economy, ecology, and music: An introduction. The World of Music, 51(1), 5-15. Retrieved from http://www.jstor.org/stable/41699860

Trehub, S. E., Becker, J., \& Morley, I. (2015). Cross-cultural perspectives on music and musicality. Philosophical Transactions: Biological Sciences, 370(1664), 19.http://www.jstor.org/stable/24504293.

\footnotetext{
${ }^{i}$ Tara Lal Shrestha, a PhD on Subaltern Studies in Native Literary Context, has published four research-based books on the subaltern themes and edited eight anthologies related to the history and struggle of the Bhutanese refugees. His area of research includes wider politico-cultural issues of the subaltern communities. $\mathrm{He}$ is currently a Lecturer in the Central Department of English, Tribhuvan University.
}

ii Bidhya Shrestha, a PhD scholar and Lecturer of the Central Department of Population Studies, Tribhuvan University, has presented papers in national and international conferences. Her area of research includes women empowerment, maternal health, and socio-cultural issues of the marginalized communities. Currently, she is on the verge of completing her $\mathrm{PhD}$.

iii Dipankar Senehang is the student of the Fourth Semester in the Central Department of English, Tribhuvan University. They have been engaged in independent research works and activism related to the issues of the subaltern communities.

${ }^{\text {iv }}$ Bibechana Sharma Timsina is the student of the Fourth Semester in the Central Department of English, Tribhuvan University. They have been engaged in independent research works and activism related to the issues of the subaltern communities. 